\section{Pinch Height of Stock Plants during Scaffold Development Affects Cutting Production}

James E. Faust

Department of Horticulture, D-136 P\&A Building, Clemson University, Clemson, SC 29634

\author{
Larry W. Grimes \\ Department of Experimental Statistics, 103 P\&A Building, Clemson University, \\ Clemson, SC 29634
}

Additional index words. antirrhinum, chrysocephalum, diascia, lavendula, osteospermum, verbena

\begin{abstract}
Stock plants of six herbaceous species (Antirrhinum $\times$ hybrida 'Primrose with Vein' L., Chrysocephalum apiculatum 'Golden Buttons', Diascia $\times$ hybrida 'Sunchimes Coral' Link \& Otto, Lavendula dentata 'Serenity' L., Osteospermum $\times$ hybrida 'Zulu' L., and Verbena $\times$ hybrida 'Lanai Bright Pink' L.) received nine different pinch treatments. Stock plants received a first pinch treatment at one of three pinch heights [low $\left(L_{1}\right)$, middle $\left(M_{1}\right)$, and high $\left.\left(H_{1}\right)\right]$ followed by a second pinch at one of three pinch heights [low $\left(L_{2}\right)$, middle $\left(\mathrm{M}_{2}\right)$, and high $\left.\left(\mathrm{H}_{2}\right)\right]$ in a $3 \times 3$ factorial arrangement. After the two pinches, cuttings were removed weekly from the stock plants. Cutting yield per stock plant increased as pinch height increased from $\mathrm{L}$ to $\mathrm{H}$ for both the first and second pinch for all species. A low first pinch followed by a low second pinch $\left(\mathrm{L}_{1} \mathrm{~L}_{2}\right)$ produced stock plants with the lowest cutting yield, while a high first pinch followed by a high second pinch $\left(\mathrm{H}_{1} \mathrm{H}_{2}\right)$ produced the stock plants with the highest cutting yield for all species, e.g., the percentage increase in cutting yield was $133 \%$ for Antirrhinum, $98 \%$ for Chrysocephalum, 144\% for Diascia, $\mathbf{8 0} \%$ for Lavendula, $250 \%$ for Osteospermum, and $44 \%$ for Verbena. This study suggests that pinch height during scaffold development of the stock plant is an important tool for increasing cutting production.
\end{abstract}

The vegetatively propagated annuals market continues to grow in the United States. Stock plants are used to produce shoot-tip cuttings for this market. Historically, several important floriculture crops have been propagated vegetatively, such as geranium (Pelargonium $\times$ hortorum L.H. Bailey) (O’Donovan, 1993), poinsettia (Euphorbia pulcherrima Willd. ex Klotzsch) (Ecke et al., 2004), chrysanthemum (Dendranthema $\times$ grandiflorum Kitam.) (Eng et al., 1983), and new guinea impatiens (Impatiens hawkeri Bull.) (Williams and Ruis, 1995), but no research has been reported on the stock plant production of more recently introduced species such as those used in this study.

A stock plant starts from a single shoot-tip cutting. After propagation, the rooted cutting is transplanted to a container or bed. The initial phase of stock plant production is termed the scaffold development phase. At this time the stock plant is pinched, i.e., apex removal, multiple times to promote lateral shoot development and build a scaffold from which future cutting production occurs. The number

Received for publication 14 May 2004. Accepted for publication 3 Sept. 2004. Technical Contribution No.4904 of the Clemson University Experiment Station. This material is based upon work supported by CSREES/USDA, underproject numberSC-1700135. Additional support for this research was provided by FIRST. Any opinions, findings, conclusions or recommendations expressed in this publication are those of the authors and do not necessarily reflect the view of the USDA. of pinches performed during the scaffold phase affects the timing and yield of cutting production (Faust and Grimes, 2004). O'Donovan (1993) recommended that geranium stock plants are initially pinched to leave a 10 to $15 \mathrm{~cm}$ tall primary stem that contains at least four nodes, then the shoots that develop after the initial pinch are pinched to two or three nodes until the peak harvest season at which time one node is left on the stem below the harvested cutting.

The scaffold phase is followed by the production phase during which time cuttings are harvested from the stock plants. Leaf removal during the production phase is recommended on poinsettia (Wilkins, 1988) and geranium (O’Donovan, 1993) stock plants since this allows for increased light penetration into the canopy and thus increased cutting production.

The number of nodes left below the pinch affects the timing of lateral shoot development and the number of potential lateral shoots. The number of nodes left on the stem below the pinch is referred to as the pinch height in this manuscript. A low pinch has relatively few nodes remaining on the stem for lateral shoot development, while a high pinch leaves a greater number of nodes remaining on the stem. A low pinch can be performed while the shoots are relatively young, but relatively few nodes are left on the stock plant. In contrast, more production time is required before a shoot has enough nodes to perform a high pinch; however, more nodes are left below the high pinch, so more potential shoots can develop. The objective of this study was to determine the effect of pinch height on the cutting yield of six vegetatively propagated herbaceous species. The results will provide growers with an improved understanding of how to manage stock plants to improve cutting yield.

\section{Materials and Methods}

Forty-five, unpinched, rooted cuttings of each of five species (Antirrhinum $\times$ hybrida 'Primrose with Vein' L., Chrysocephalum apiculatum 'Golden Buttons', Diascia $\times$ hybrida 'Sunchimes Coral' Link \& Otto., Osteospermum $\times$ hybrida 'Zulu' L., and Verbena $\times$ hybrida 'Lanai Bright Pink' Groenl. \& Ruempl.) and 54 rooted cuttings of Lavendula dentata 'Serenity' L. were transplanted into 16.5-cm-diameter (2.2-L) containers at the start of the experiment. One cutting was planted in each container, and each plant represented an experimental unit. Containers were placed at $30 \times 30-\mathrm{cm}$ spacing (center-to-center), so that the canopy of neighboring plants did not overlap during the experiment.

Fifteen Antirrhinum, Diascia, Osteospermum and Verbena plants and eighteen Lavendula plants were randomly treated with one of the three following pinch treatments on the primary shoot: low $\left(\mathrm{L}_{1}\right)$, middle $\left(\mathrm{M}_{1}\right)$, or high $\left(\mathrm{H}_{1}\right)$. Pinch height was defined by the number of nodes remaining on the shoot following the pinch. The timing of the pinch treatments and the number of nodes left below each pinch was unique for each species (Table 1). Following the first pinch, lateral shoots developed, then a second pinch was performed on the lateral shoots. The second pinch was also performed at one of three heights: low $\left(\mathrm{L}_{2}\right)$, middle $\left(\mathrm{M}_{2}\right)$, or high $\left(\mathrm{H}_{2}\right)$, as defined in Table 1. The result was nine pinch treatment combinations arranged in a $3 \times 3$ factorial design. The nine individual treatment combinations are labeled as: $\mathrm{L}_{1} \mathrm{~L}_{2}$, $\mathrm{L}_{1} \mathrm{M}_{2}, \mathrm{~L}_{1} \mathrm{H}_{2}, \mathrm{M}_{1} \mathrm{~L}_{2}, \mathrm{M}_{1} \mathrm{M}_{2}, \mathrm{M}_{1} \mathrm{H}_{2}, \mathrm{H}_{1} \mathrm{~L}_{2}, \mathrm{H}_{1} \mathrm{M}_{2}$ and $\mathrm{H}_{1} \mathrm{H}_{2}$. The main effects for pinch height are described with a single letter, e.g., L, M and $\mathrm{H}$ for the low, middle and high pinches, respectively.

The timing of the pinch treatments varied on the first and second pinch for each species (Table 1). For example, the first pinch was applied to the primary shoot of Antirrhinum on day 7, and 2, 4, and 6 nodes were left on the stock plant for the $\mathrm{L}_{1}, \mathrm{M}_{1}$ and $\mathrm{H}_{1}$ treatments, respectively. Thus, the amount of tissue removed during the first pinch varied with the pinch height treatment. The second pinch was performed as soon as the shoots had developed enough nodes for the pinch to take place, e.g., for Antirrhinum the second pinch was applied on day 21, 27 or 33, and 2, 4, or 6 nodes were left below the pinch for the $\mathrm{L}_{2}, \mathrm{M}_{2}$ or $\mathrm{H}_{2}$ treatment, respectively.

Following the two pinch treatments, cuttings were removed weekly from the stock plants when the developing shoot met the following two criteria. The cutting stem was a specified length (Table 2) and two nodes or one node pair, depending on leaf arrangement of 
Table 1. The pinch dates and the number of nodes remaining on the shoots after the pinch for each of the nine pinch height treatments and six species.

\begin{tabular}{|c|c|c|c|c|c|c|}
\hline \multirow[b]{2}{*}{ Species } & \multicolumn{2}{|c|}{$\begin{array}{l}\text { Pinch ht } \\
\text { treatment }\end{array}$} & \multicolumn{2}{|c|}{$\begin{array}{c}\text { Pinch date } \\
\text { (days after transplant) }\end{array}$} & \multicolumn{2}{|c|}{$\begin{array}{c}\text { Nodes remaining } \\
\text { on shoots after }\end{array}$} \\
\hline & 1st pinch & 2nd pinch & 1st pinch & 2nd pinch & 1st pinch & 2nd pinch \\
\hline \multicolumn{7}{|c|}{ Antirrhinum } \\
\hline & Low & Low & 7 & 21 & 2 & 2 \\
\hline & Low & Middle & 7 & 27 & 2 & 4 \\
\hline & Low & High & 7 & 33 & 2 & 6 \\
\hline & Middle & Low & 7 & 21 & 4 & 2 \\
\hline & Middle & Middle & 7 & 27 & 4 & 4 \\
\hline & Middle & High & 7 & 33 & 4 & 6 \\
\hline & High & Low & 7 & 21 & 6 & 2 \\
\hline & High & Middle & 7 & 27 & 6 & 4 \\
\hline & High & High & 7 & 33 & 6 & 6 \\
\hline \multicolumn{7}{|c|}{ Chrysocephalum } \\
\hline & Low & Low & 10 & 35 & 4 & 2 \\
\hline & Low & Middle & 10 & 35 & 4 & 4 \\
\hline & Low & High & 10 & 35 & 4 & 6 \\
\hline & Middle & Low & 10 & 35 & 6 & 2 \\
\hline & Middle & Middle & 10 & 35 & 6 & 4 \\
\hline & Middle & High & 10 & 35 & 6 & 6 \\
\hline & High & Low & 10 & 35 & 8 & 2 \\
\hline & High & Middle & 10 & 35 & 8 & 4 \\
\hline & High & High & 10 & 35 & 8 & 6 \\
\hline \multicolumn{7}{|l|}{ Diascia } \\
\hline & Low & Low & 7 & 17 & 2 & 2 \\
\hline & Low & Middle & 7 & 24 & 2 & 4 \\
\hline & Low & High & 7 & 33 & 2 & 6 \\
\hline & Middle & Low & 7 & 17 & 4 & 2 \\
\hline & Middle & Middle & 7 & 24 & 4 & 4 \\
\hline & Middle & High & 7 & 33 & 4 & 6 \\
\hline & High & Low & 7 & 17 & 6 & 2 \\
\hline & High & Middle & 7 & 24 & 6 & 4 \\
\hline & High & High & 7 & 33 & 6 & 6 \\
\hline \multicolumn{7}{|c|}{ Lavendula } \\
\hline & Low & Low & 2 & 26 & 3 & 3 \\
\hline & Low & Middle & 2 & 32 & 3 & 5 \\
\hline & Low & High & 2 & 39 & 3 & 7 \\
\hline & Middle & Low & 4 & 26 & 5 & 3 \\
\hline & Middle & Middle & 4 & 32 & 5 & 5 \\
\hline & Middle & High & 4 & 39 & 5 & 7 \\
\hline & High & Low & 8 & 26 & 7 & 3 \\
\hline & High & Middle & 8 & 32 & 7 & 5 \\
\hline & High & High & 8 & 39 & 7 & 7 \\
\hline \multicolumn{7}{|c|}{ Osteospermum } \\
\hline & Low & Low & 11 & 49 & 5 & 2 \\
\hline & Low & Middle & 11 & 56 & 5 & 6 \\
\hline & Low & High & 11 & 63 & 5 & 10 \\
\hline & Middle & Low & 32 & 56 & 10 & 2 \\
\hline & Middle & Middle & 32 & 63 & 10 & 6 \\
\hline & Middle & High & 32 & 70 & 10 & 10 \\
\hline & High & Low & 42 & 63 & 15 & 2 \\
\hline & High & Middle & 42 & 70 & 15 & 6 \\
\hline & High & High & 42 & 84 & 15 & 10 \\
\hline \multicolumn{7}{|l|}{ Verbena } \\
\hline & Low & Low & 5 & 21 & 2 & 2 \\
\hline & Low & Middle & 5 & 29 & 2 & 4 \\
\hline & Low & High & 5 & 34 & 2 & 6 \\
\hline & Middle & Low & 10 & 21 & 4 & 2 \\
\hline & Middle & Middle & 10 & 29 & 4 & 4 \\
\hline & Middle & High & 10 & 34 & 4 & 6 \\
\hline & High & Low & 21 & 29 & 6 & 2 \\
\hline & High & Middle & 21 & 34 & 6 & 4 \\
\hline & High & High & 21 & 41 & 6 & 6 \\
\hline
\end{tabular}

Table 2. The experimental dates and the specified cutting stem length for each of the six species.

\begin{tabular}{lccc}
\hline Species & $\begin{array}{c}\text { Transplant } \\
\text { date }\end{array}$ & $\begin{array}{c}\text { Final cutting } \\
\text { harvest date }\end{array}$ & $\begin{array}{c}\text { Cutting stem } \\
\text { length }(\mathrm{cm})\end{array}$ \\
\hline Antirrhinum & 20 Dec. 2002 & 31 Mar. 2003 & 3.8 \\
Chrysocephalum & 7 Jan. 2003 & 14 Apr. 2003 & 3.2 \\
Diascia & 20 Dec. 2002 & 17 Mar. 2003 & 3.8 \\
Lavendula & 13 Feb. 2003 & 19 May 2003 & 3.2 \\
Osteospermum & 25 Nov. 2002 & 28 Apr. 2003 & 2.5 \\
Verbena & 6 Dec. 2002 & 12 Mar. 2003 & 2.5 \\
\hline
\end{tabular}

each species, remained on the shoot following cutting removal. The number of cuttings harvested per stock plant was recorded weekly.

The experimental dates were unique for each species (Table 2). From 25 Nov. to 19 May themean daily light integral was $10.2 \mathrm{~mol} \cdot \mathrm{m}^{-2} \cdot \mathrm{d}^{-1}$ and the mean greenhouse air temperature was $22.9^{\circ} \mathrm{C}$. Ambient photoperiods were provided throughout the experiment. Plants were fertilized twice weekly with $20 \mathrm{~N}-8.6 \mathrm{P}-16.6 \mathrm{~K}$ Peat-Lite Special (O.M. Scott, Marysville, Ohio) at $250 \mathrm{mg} \cdot \mathrm{L}^{-1} \mathrm{~N}$. Water was applied as needed the remainder of the week.

For each species, three pinch height treatments were applied during the first and second pinches resulting in a $3 \times 3$ factorial design. The individual treatments were arranged in a completely randomized pattern inside the greenhouse. ANOVA were performed for each species and at each cumulative harvest date using PROC GLM (SAS Institute, Cary, N.C.). LSD (5\% level) was used to determine differences between the main effects (pinch height) at each harvest date. The final cumulative cutting yields for all nine subclasses (first and second pinch height combinations) were compared using pairwise comparisons with LSD at the $5 \%$ level.

\section{Results}

Pinch height affected the final cumulative cutting yield for all species, while no statistical interaction was observed between the pinch height of the first and second pinches (Table 3); therefore, the effect of pinch height on the first and second pinches exhibited an additive effect on cutting yield. Final cutting yield increased as pinch height increased for both the first and second pinches (Table 4). For example, the main effect means for Antirrhinum were 81,102 , and 118 total cuttings for $\mathrm{L}_{1}, \mathrm{M}_{1}$, and $\mathrm{H}_{1}$, and 71,111 , and 118 total cuttings for $\mathrm{L}_{2}, \mathrm{M}_{2}$, and $\mathrm{H}_{2}$. The combined first and second pinch heights yielded 60, 108, to 140 cuttings for the $\mathrm{L}_{1} \mathrm{~L}_{2}, \mathrm{M}_{1} \mathrm{M}_{2}$, and $\mathrm{H}_{1} \mathrm{H}_{2}$ treatments, respectively. Comparing $\mathrm{L}_{1} \mathrm{~L}_{2}$ to $\mathrm{H}_{1} \mathrm{H}_{2}$ for the other species shows cutting yield increases of $98 \%, 144 \%, 80 \%, 250 \%$, and $44 \%$ for Chrysocephalum, Diascia, Lavendula, Osteospermum, and Verbena, respectively. In general, differences between the L and M treatments were more frequently significant than between $\mathrm{M}$ and $\mathrm{H}$.

The effect of pinch height on the cutting yield over time displayed one of two distribution patterns for all six species as demonstrated by Lavendula (Fig. 1). For example, the first pinch of Lavendula resulted in no significant treatment differences from day 46 to 67 , while $\mathrm{H}_{1}$ had a higher cutting yield than $\mathrm{L}_{1}$ from day 74 to 95 (Fig. 1A). Similarly, the first and second pinch of Antirrhinum, Chrysocephalum, and Verbena and the first pinch of Diascia showed no treatment effects during the first 2 to 5 weeks of cutting production, thereafter consistent treatment effects were observed through the duration of the experiment (data not shown). The second cutting distribution pattern over time is demonstrated by the second pinch treatment for Lavendula (Fig. 1B). For example, 
Table 3. Significance of pinch height treatment on the final cumulative cutting yield for each species. ANOVA were performed with the SAS GLM procedure (SAS Institute, Cary, N.C.).

\begin{tabular}{lcccccc}
\hline Pinch ht & \multicolumn{5}{c}{ Species } \\
\cline { 2 - 7 } treatment & Antirrhinum & Chrysocephalum & Diascia & Lavendula & Osteospermum & Verbena \\
\hline Significance & $* * *$ & $* * *$ & $* * *$ & $* *$ & $* * *$ & $*$ \\
$\quad$ First (F) & $* * *$ & $* * *$ & $* * *$ & $* * *$ & $* * *$ & $* * *$ \\
Second (S) & NS & NS & NS & NS & NS & NS \\
F $\times$ S & NS,$* * * * * * *$ NS
\end{tabular}

Table 4. The effect of the first and second pinch height on the final cumulative cutting yield per stock plant of six herbaceous species. Each stock plant received one of three pinch height treatments for the first and second pinch resulting in a $3 \times 3$ factorial arrangement. Low pinches had the fewest nodes remaining below the pinch, while high pinches had the most nodes remaining below the pinch. The node number remaining on the stock plant below each pinch varied with species (Table 1). The cutting yield represents the total cuttings harvested over 101, 97, 87, 95, 154, and $96 \mathrm{~d}$ for Antirrhinum, Chyrsocephalum, Diascia, Lavendula, Osteospermum, and Verbena, respectively.

\begin{tabular}{lcccc}
\hline & & \multicolumn{3}{c}{$\begin{array}{c}\text { Final cutting yield } \\
\text { (cuttings/stock plant) }\end{array}$} \\
\cline { 3 - 5 } Species & & \multicolumn{3}{c}{ 2nd pinch ht } \\
\cline { 3 - 5 } Antirrhinum & Low & Middle & High \\
& Low & $60 \mathrm{e}$ & $91 \mathrm{~cd}$ & $93 \mathrm{~cd}$ \\
Chrysocephalum & Middle & $76 \mathrm{de}$ & $108 \mathrm{bc}$ & $121 \mathrm{ab}$ \\
& High & $80 \mathrm{~d}$ & $133 \mathrm{a}$ & $140 \mathrm{a}$ \\
& Low & $53 \mathrm{f}$ & $64 \mathrm{ef}$ & $77 \mathrm{cde}$ \\
Diascia & Middle & $71 \mathrm{cde}$ & $81 \mathrm{bcd}$ & $93 \mathrm{ab}$ \\
& High & $69 \mathrm{de}$ & $85 \mathrm{bc}$ & $105 \mathrm{a}$ \\
& Low & $63 \mathrm{f}$ & $98 \mathrm{de}$ & $117 \mathrm{~cd}$ \\
Lavendula & Middle & $89 \mathrm{e}$ & $134 \mathrm{abc}$ & $146 \mathrm{ab}$ \\
& High & $113 \mathrm{~cd}$ & $128 \mathrm{bc}$ & $154 \mathrm{a}$ \\
Osteospermum & Low & $44 \mathrm{~d}$ & $54 \mathrm{~cd}$ & $63 \mathrm{bc}$ \\
& Middle & $46 \mathrm{~d}$ & $64 \mathrm{bc}$ & $70 \mathrm{ab}$ \\
Verbena & High & $54 \mathrm{~cd}$ & $65 \mathrm{~b}$ & $79 \mathrm{a}$ \\
& Low & $16 \mathrm{f}$ & $31 \mathrm{de}$ & $42 \mathrm{bc}$ \\
& Middle & $29 \mathrm{e}$ & $47 \mathrm{~b}$ & $48 \mathrm{~b}$ \\
& High & $39 \mathrm{~cd}$ & $49 \mathrm{ab}$ & $56 \mathrm{a}$ \\
& Low & $153 \mathrm{e}$ & $193 \mathrm{bcd}$ & $211 \mathrm{abc}$ \\
& Middle & $187 \mathrm{~cd}$ & $207 \mathrm{abc}$ & $200 \mathrm{abcd}$ \\
& High & $179 \mathrm{~d}$ & $214 \mathrm{ab}$ & $220 \mathrm{a}$ \\
\hline
\end{tabular}

${ }^{\mathrm{z}}$ Mean separation within rows and columns for each species by LSD, $P \leq 0.05$.

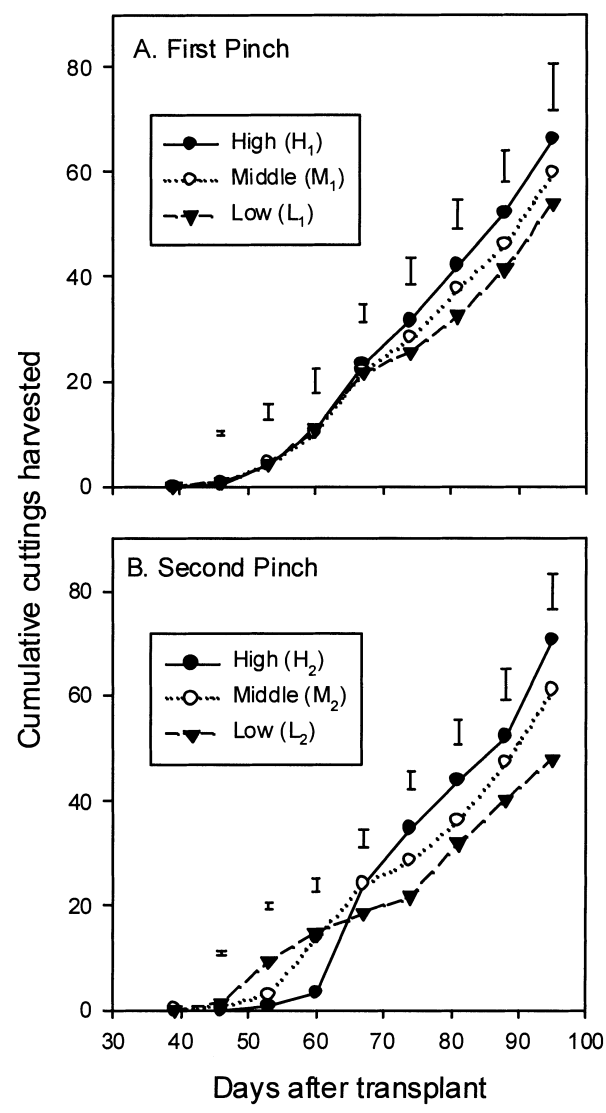

the second pinch of Lavendula resulted in $\mathrm{L}_{2}$ producing more cuttings than $\mathrm{H}_{2}$ on days 53 and 60 , while $\mathrm{H}_{2}$ produced more cuttings than $\mathrm{L}_{2}$ from day 67 through the remainder of the experiment (day 95). Similarly, the L treatments initially produced more cuttings than $\mathrm{H}$ for the first and second pinch of $O s$ teospermum and the second pinch of Diascia while the $\mathrm{H}$ treatments eventually produced the most cuttings (data not shown).

\section{Discussion}

Low pinch heights resulted in the lowest cutting production for all six species in this study. This is in agreement with the observations made on geranium stock plants (O’Donovan, 1993). We hypothesize that there are two reasons for this response. First, the onset of lateral shoot development following a pinch appeared to be slower for $\mathrm{L}$ than the $\mathrm{M}$ and $\mathrm{H}$ treatments. In some cases, axillary buds began to develop lateral shoots prior to

Fig. 1. The effect of pinch height of the first and second pinches on the main effect means of cumulative cuttings harvested over time from Lavendula 'Serenity' stock plants. Pinch height refers to the number of nodes remaining on the stem below the pinch site. The fewest nodes were left below the low pinch, while the most nodes were left below the high pinch. Vertical bars represent the $\mathrm{LSD}_{0.05}$ for each harvest date. receiving a high pinch. The increased lag time from pinch to first unfolded leaf on the lateral shoots for L may be a result of a lack of axillary bud maturity at the time of the pinch. Second, the lowest nodes on the stem usually had the smallest leaves, i.e., leaf size increased on the stem as the node position increased from the base of the stem to the apex; therefore, stock plants receiving low pinches had relatively low leaf areas that resulted in lower light interception. The combined effect is that $\mathrm{L}$ treatments produced relatively small stock plants that had slower shoot growth and development than the $\mathrm{M}$ or $\mathrm{H}$ pinch height treatments.

The number of shoots that develop in a given area can be limited by the number of nodes in the canopy or the daily light integral (Faust et al., 2005). In this experiment there was not always a significant difference between the $\mathrm{H}$ and $\mathrm{M}$ treatments despite the differences in the number of nodes remaining after the pinch treatments. Therefore, the daily light integral provided during this experiment may have limited shoot development. Grueber (1985) reported no cutting yield benefit when 9,11 , or 13 nodes were left on the primary stem following the initial pinch of poinsettia stock plants. We hypothesize that $\mathrm{H}$ has a greater potential benefit to cutting production if the daily light integral is sufficiently high to support shoot development from all the nodes left on the stock plant. Moe (1994) proposed that a daily light integral of 10 to $20 \mathrm{~mol} \cdot \mathrm{m}^{-2} \cdot \mathrm{d}^{-1}$ is optimal for medium light crops and 20 to $30 \mathrm{~mol} \cdot \mathrm{m}^{-2} \cdot \mathrm{d}^{-1}$ for high light crops. All of the species used in this study perform well in full sunlight locations outdoors, so we expect that $>10 \mathrm{~mol} \cdot \mathrm{m}^{-2} \cdot \mathrm{d}^{-1}$ would be beneficial to cutting yield.

Flowering is closely related to node position with the probability of flowering increasing as node position increases; therefore, the $\mathrm{H}$ treatments have the potential to negatively affect cutting quality by increasing flower development on the nodes harvested as part of the cuttings (Evans et al., 1992). It is possible that $\mathrm{H}$ allows the production of lateral shoots that are in close proximity to the terminal flower and are more likely to initiate a flower at a relatively low node count. The result is a cutting that may have flower buds present which may result in earlier flowering than desired. Although no negative effects were observed from the $\mathrm{H}$ treatments applied in this study, premature flower development may be more of an issue on stock plants produced under environmental conditions that are more conducive to flowering, such as the higher solar radiation and longer photoperiods typical of summer production (Erwin et al., 2004).

Cutting yield during the initial weeks of production were affected by the timing of the pinch treatments. Since the second pinch height treatment was applied on different dates, the initial weeks of cutting harvest resulted in the $\mathrm{L}_{2}$ treatments initially producing more cuttings than $\mathrm{M}_{2}$ and $\mathrm{H}_{2}$ for Diascia, Lavendula and Osteospermum; however, when the $\mathrm{M}_{2}$ and $\mathrm{H}_{2}$ treatments started to produce cuttings, they rapidly exceeded the cumulative yield of the $\mathrm{L}_{2}$ treatments (Fig. 1). The differences between the pinch height treatments became 
clearly defined after 2 to 5 weeks of cutting production.

This study suggests that the pinch height during the scaffold development phase of stock plant production can significantly impact cutting yield. In some cases, Lallowed for cuttings to be harvested more quickly than $\mathrm{M}$ and $\mathrm{H}$; however, the cutting production of $\mathrm{M}$ and $\mathrm{H}$ treatments quickly exceeded L. Therefore, low pinches during scaffold development should be avoided, while medium or high pinches improve cutting yield while having a minimal impact on the timing of cutting production. This research should provide commercial stock producers with an increased understanding of how to manage stock plants to improve cutting yields from stock plants.

\section{Literature Cited}

Ecke, III, P., J.E. Faust, A. Higgins, and J. Williams. 2004. The Ecke poinsettia manual, p. 13-20.3rd ed. Ball Publ., Batavia, Ill.

Eng, R.Y.N., M.J. Tsujita, B. Grodzinski, and R.G. Dutton. 1983. Production of chrysanthemum cuttings under supplementary lighting and carbon dioxide enrichment. HortScience 18:878-879.

Erwin, J.E., N. Mattson, and R. Warner. 2004 Light effects on annual bedding plants, p. 62-71. In: P. Fisher and E. Runkle (eds.). Lighting up profits. Meister Media Worldwide, Willoughby, Ohio.

Evans, M.R., H.F. Wilkins, and W.P. Hackett. 1992. Meristem ontogenetic age as the controlling factor in long-day floral initiation in poinsettia. J. Amer. Soc. Hort. Sci. 117:961-965.

Faust J.E. and L.W. Grimes 2004. Cutting production is affected by pinch number during scaffold development of stock plants. HortScience (in press).
Faust, J.E., V. Holcombe, N.C. Rajapakse, and Desmond R. Layne. 2005. The effect of daily light integral on bedding plant growth and flowering. HortScience (in press)

Grueber, K.L. 1985. Control of lateral branching and reproductive development in Euphorbia pulcherrima Willd. ex Klotzsch. PhD diss. Univ. Minn., Minneapolis.

Moe, R. 1994. Vekstfysiologiske aspekter med høege belysningsstyrker. Gartneryrket 84:8-13.

O’Donovan, E.J. 1993. Stock plants, p. 75-85. In: J.W. White (ed.). Geranium IV. 4th ed. Ball Publishing, Geneva, Ill.

Wilkins, H.F. 1988. Techniques to maximize cutting production. Acta. Hort. 226:137-143.

Williams, J.E. and P. Ruis. 1995. Stock plant production, p. 65-79. In: W. Banner and M. Klopmeyer (eds.). New guinea impatiens: A Ball guide. Ball Publ., Batavia Ill. 